\title{
An analysis of potential investment returns and their determinants of poplar plantations in state-owned forest enterprises of China
}

\author{
Yangyang Wang • Guangxin Bai • Guofan Shao • Yukun Cao
}

Received: 23 February 2013/Accepted: 11 January 2014/Published online: 22 January 2014

(C) The Author(s) 2014. This article is published with open access at Springerlink.com

\begin{abstract}
China's state-owned forest enterprises have been important national timber production bases and their timber resources have been severely degraded during the past decades. About one-third of the state-owned forestland has been classified as commercial forestland, but no economic mechanisms have been laid out on governing timber plantations under market economy. This paper demonstrates the potential investment returns and analyzes factors that directly influence the returns of fast-growing poplar plantations in a state owned-forest enterprise, China Jilin Forest Industry Group (CJFIG), in northeastern China. We examined practically possible ranges of mean annual increment (MAI), general inflation rate, rate of forest fund, and interest rate in the study area. We then computed net present values (NPV), equivalent annual income (EAI) and internal rate of return (IRR) by using the minimum, medium, and maximum values of the each determinant above. Results showed NPV ranged from $\$ 1,024$ to $\$ 6,925 \mathrm{ha}^{-1}$, EAI ranged from $\$ 120$ to $\$ 623 \mathrm{ha}^{-1}$ year $^{-1}$, and IRR ranged from 13.2 to $29.3 \%$. We show that growing poplar plantations could be two times more profitable than managing the existing natural forests in CJFIG by referring to EAI values. Improving MAI is the most effective way to increase both NPV and IRR while changes in the one-time tax at timber harvesting or changes in inflation rate have the least effect on NPV and IRR among the determinants studied. Discount rate, which can be easily manipulated by obtaining subsidies and policy-based loans, also has substantial influence on NPV. The state owned forest enterprises in China have special advantages to obtain relatively high economic returns in developing fast-growing plantation forests under market economy.
\end{abstract}

Y. Wang · G. Bai · Y. Cao

College of Economics and Management, Northeast Forestry University,

Harbin 150040, Heilongjiang, China

Y. Wang $(\bowtie) \cdot$ G. Shao

Department of Forestry and Natural Resources, Purdue University, West Lafayette,

IN 47906, USA

e-mail: wang1361@purdue.edu

G. Bai

China Jilin Forest Industry Group Co., Ltd., Changchun 130021, Jilin, China 
Keywords Forest regeneration - Poplar plantation · Investment return ·

Sustainable forestry $\cdot$ Fast-growing plantation

\section{Introduction}

Investment in forest plantations is one of the most important business decisions for reliable future returns in many forestry areas around the world (Cubbage et al. 2007, 2010; Shao and $\mathrm{Li}$ 2010). As the most populated country of the world, China has made extraordinary efforts in developing forest plantations during the past six decades (Zhang and Song 2006). By 2004-2008, China's forest plantation area has reached 61.7 million ha, accounting for one-third of planted forests in area in the world (Huang et al. 2012). However, China's forest plantations are still relatively young and unproductive. Unit-area stocking for planted forests is about only $20 \%$ of that for natural forests in China (Dai et al. 2013), and the productivity of entire forests in China is much lower than that in the United States (Shao et al. 2011). At the same time, wood consumption in China has undergone tremendous increases as a result of a booming economy and is projected to triple between 2008 and 2020 ( $\mathrm{He}$ and $\mathrm{Xu}$ 2011). Therefore, the development of fast-growing forest plantations in China is necessary to meet the needs of increasingly high timber consumptions.

While there are many successful experiences in growing forest plantations in tropical and sub-tropical regions, increasingly much attention has been paid on short-rotation, fastgrowing poplar plantations in the temperate (Heilman 1999; Liberloo et al. 2006) and boreal (Elferjani et al. 2013) zones on Earth. Poplar plantations accounts for $13.5 \%$ of China's total forest plantations in area (Wilske et al. 2009). Although poplar plantations still have limited contributions to the timber supply worldwide, their area has been increasing rapidly, particularly in China, which was more extensive than the rest of the world's poplar plantations combined. The total area of planted poplar reported in 2012 was 8.6 million ha over the world, of which $87.5 \%$ or 7.57 million ha were found in China. However, most poplar plantations have been developed as shelterbelts to protect farmland, rangeland, and settlements in the semiarid area of China. These poplar plantations have been transpiring groundwater and lowering water tables, and their success in future development in the region is uncertain (Wilske et al. 2009). At the same time, forest regions in northeastern China, where climate is appropriate for growing poplar forests, are occupied mostly by China's state-owned forest enterprises, and their forestry system is restricted by the national forestry regulations that had been formulated before China's economic reform in the early 1980s (Yu et al. 2011). For example, about one-third of forestland in the state-owned forest enterprises is classified as timber or commercial forest under the national forestland classification system (Dai et al. 2013). Bai (2009) argued that the management of commercial forest harvesting should be regulated by fluctuated markets rather than be restricted by fixed forest rotations that were formulated for non-commercial forests by the government.

Financial returns of forest plantations are indeed an important concern around the world. The net present value (NPV), equivalent annual income (EAI), and internal rate of return (IRR) were often used as indicators for assessing economic returns of poplar plantations (Keča et al. 2012). Some assessments have analyzed these financial criteria already. For instance, Sedjo (1999) stated that intensively managed forest plantations in the 
southern hemisphere are much more profitable than those in the northern hemisphere. Cubbage et al. (2010) calculated the NPV of exotic plantations of South America were generally greater than other countries in northern hemisphere. Wang et al. (2008) figured out the IRR in the plantations of eucalyptus (Eucalyptus grandis) with different clones ranged from 15.4 to $57.1 \%$ in southern China.

Net present values, EAI and IRR are affected differently by biological, environmental, and economic factors, and it is important for forestland owners to know which factor is more dominant than another. Few researches have analyzed these correlation factors with empirical data in plantation financial analysis. There is no systematic research on economic returns of plantations in the stated-owned forestry area of China. Our research tended to use the case of China Jilin Forest Industry Group (CJFIG) to help forest industry and academics learn more about the opportunities in China's plantation investment and inform relevant policy makers and investors about economically sound forest management in China.

\section{Study site and methods}

The CJFIG, a typical state-owned forest enterprise in northeastern China, has about $1,200,000$ ha of forests, of which 73,000 ha are planted forests of larch, pine, and poplar species. The forests were located on eastern aspect of Changbai Mountain (Tang et al. 2009), geographically ranging from $40^{\circ} 52^{\prime}$ to $46^{\circ} 18^{\prime} \mathrm{N}$ and from $121^{\circ} 38^{\prime}$ to $131^{\circ} 19^{\prime} \mathrm{E}$. The elevation of the study site was about $800 \mathrm{~m}$ above sea level, mean annual temperature was $3.0^{\circ} \mathrm{C}$, frost-free period was 130 days, and mean annual precipitation was $750 \mathrm{~mm}$. The soil at the study was dark brown forest soil with rich nutrients, suitable for cultivating short-rotation poplar plantations (Bai 2009).

The CJFIG has had an experience of planting and managing 18,032 ha of poplar plantations since the 1970 s, which provided us with necessary data on forest regeneration, management activities, and timber harvesting for this research (Table 1). CJFIG has signed a 1.6 billion US dollars strategic collaborate plan with the National Development Bank of China to develop additional 80,000 ha of poplar plantations for wood board production in the next a few years in eastern Jilin Province.

The NPV of poplar plantations in year $n$ was computed as (Bullard and Straka 1998):

$$
\mathrm{NPV}_{n}=\sum_{t=1}^{n} \frac{\left[R_{t}-\left(R_{t}-C_{t}\right) \times T\right] \times(1+f)^{t}}{(1+i)^{t}}-\sum_{t=1}^{n} \frac{C_{t} \times(1+f)^{t}}{(1+i)^{t}}
$$

where $R_{t}=$ the income from timber to residue sales as a result of thinning and harvesting at time $t, C_{t}=$ the cost at time $t$ (including expenses in site preparation, planting and replanting, stand tending, pruning, fertilization, and management) (Table 1), $i=$ the aftertax discount rate included inflation, which was calculated as (Bullard et al. 2001)

$$
i=(r+f+r \times f) \times(1-T)
$$

$r=$ the real interest rate, $f=$ the inflation rate, and $T=$ the tax rate.

The EAI was computed as (Duerr 1960): 
Table 1 Costs involved in the development and management of poplar plantations by CJFIG (US\$ ha ${ }^{-1}$ )

\begin{tabular}{|c|c|c|c|c|c|c|}
\hline Activity & $\begin{array}{l}\text { Site } \\
\text { preparation }\end{array}$ & $\begin{array}{l}\text { Planting and } \\
\text { replanting }\end{array}$ & $\begin{array}{l}\text { Stand } \\
\text { tending }\end{array}$ & Pruning & Fertilization & Management \\
\hline Year 1 & 230 & 212 & 55 & & & 35 \\
\hline Year 2 & & 212 & 110 & & & 35 \\
\hline Year 3 & & & 110 & & 86 & 35 \\
\hline Year 4 & & & 110 & 5 & & 35 \\
\hline Year 5 & & & 55 & & 105 & 35 \\
\hline Year 6 & & & & 5 & & 35 \\
\hline Year 7 & & & & 5 & & 35 \\
\hline Year 8 & & & & & & 35 \\
\hline Year 9 & & & & & 140 & 35 \\
\hline $\begin{array}{l}\text { Year } \\
10-15\end{array}$ & & & & & & 35 \\
\hline
\end{tabular}

The exchange rate used was US $\$ 1=$ CNY¥6.4855 computed as an average level in 2011

$$
\mathrm{EAI}=\mathrm{NPV} \times \frac{r \times(1+r)^{t}}{(1+r)^{t}-1}
$$

We obtained EAI values for the existing natural commercial forests that are harvested in year 0 before planting poplar forests and compared them with EAI values for poplar plantations.

The IRR was then derived when NPV $=0$ with Eq. 1 .

We quantified values of relevant variables in Eq. 1 based on data collected from the existing 18,032 ha of poplar plantations and conducted simulation analysis and sensitivity analysis for the future 80,000 ha of poplar plantations for wood board production in CJLFIG. The forestlands potentially available for developing poplar plantations are covered mainly by natural forests that have been logged repeatedly during the past five decades (Fig. 1). The productivity of such commercial forests is far below that of poplar plantations. The unit-area stocking of these natural commercial forests is about only $150 \mathrm{~m}^{3} \mathrm{ha}^{-1}$.

Forest density for intensive management is 2,000 trees $\mathrm{ha}^{-1}$, and the rotation was 15 years in this case. The mean annual increment (MAI) of poplar plantations was 10-20 $\mathrm{m}^{3} \mathrm{ha}^{-1}$ year $^{-1}$ depending on genetic selection and site fertility. In this study, we divided the range of MAI into three even levels 10, 15, and $20 \mathrm{~m}^{3} \mathrm{ha}^{-1}$ year $^{-1}$ (Table 2). Timber outcome percentage was $60 \%$ for final cutting and $50 \%$ for thinning, and $30 \%$ of logging residue from the final cutting and $20 \%$ from thinning were used as wood board production materials. The cost of timber harvesting and thinning was $\$ 25 \mathrm{~m}^{-3}$ and residue collection was $\$ 12 \mathrm{~m}^{-3}$. The price of poplar timber of CJLFIG was $\$ 108 \mathrm{~m}^{-3}$ and polar residue was $\$ 24 \mathrm{~m}^{-3}$ in 2012 . Due to repeated harvesting of natural forests in CJFIG, natural forests could produce only small-size, low-grade hardwood timber. On average, the natural-forest timber price was about $50 \%$ higher than poplar timber price in 2012. The price of wood residue from the natural forests was the same as that from poplar plantations.

Because China's state-owned forestland is protected from selling to other land use, we assumed that land value was 0 in this study. As a result, the subsequent costs, such as policy cost and time cost became the main expenditures in the construction of industrial poplar plantations. Agricultural specialty tax was abolished in 2004 but value added tax 

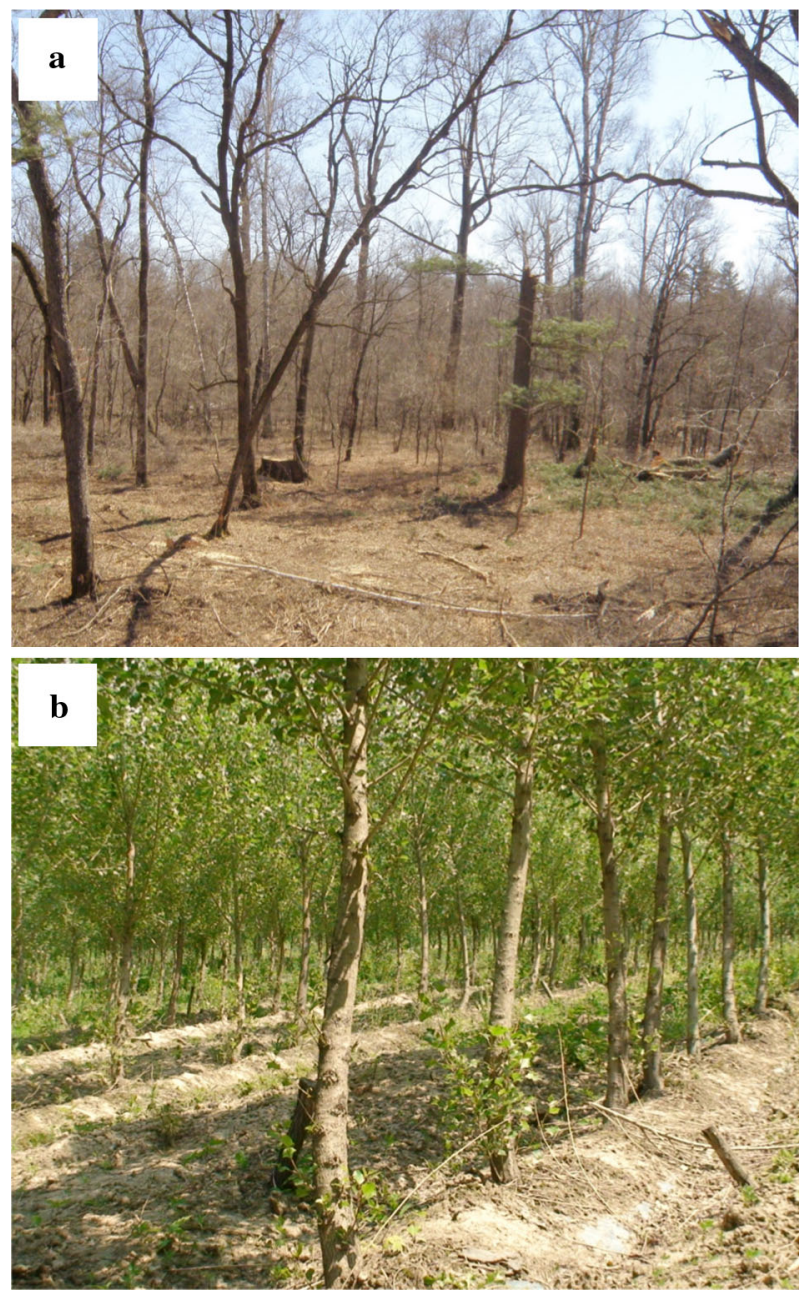

Fig. 1 A visual comparison of natural and poplar plantation forests in CJLFIG (a an existing natural forest, picture taken by Zhengji Piao, and $\mathbf{b}$ a poplar plantation, picture taken by Guofan Shao)

could be waived at forest harvesting because all the timber harvested is used internally (self-sufficient) by CJFIG. However, there is a rate of forest fund (RFF), a type of tax at harvest, which is collected by national and provincial governments and used exclusively for afforestation or reforestation. Theoretically, a forest enterprise that has paid forest fund is able to get part of forest fund back when they regenerate forests from their logged area. The amount of RFF is no more than $10 \%$ from the national government but another up to $17 \%$ from the provincial government. In this study, we used three levels of RFF 10, 18, and $27 \%$ in computing NPV and IRR.

China's inflation rate ranged from -2.2 to $27.7 \%$ but was largely between 2 and $4 \%$ in the past decades. Accordingly, we included three optional general inflation rates of 2, 4 and $6 \%$ in this study. China's nominal interest rate ranged from 5.3 to $11.0 \%$ in the past decades. Recently, the benchmark interest rate in China was $6.5 \%$ on average. There is a 


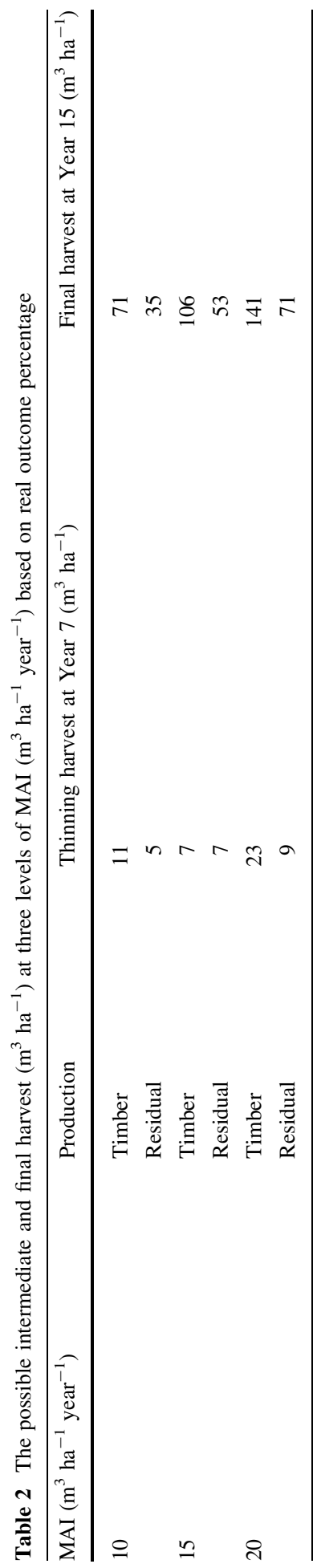


1.5-3.0 \% discount of forest loan, a subsidy from the national government, which makes the actual interest rate goes down to $4.0-8.0 \%$ by forest enterprises and private forest landowners. We divided the range of actual interest rate into three levels: 4.0, 6.0, and $8.0 \%$.

We computed NPV and IRR from all the combinations of three reasonable options of MAI, inflation rate, RFF and interest rate. To evaluate the significance of contributions from each variable to NPV and IRR, we performed the Mann-Whitney U test between any two levels of change with the variable.

\section{Results}

There was almost no investment in the growth of natural commercial forests and the NPV of the existing natural commercial forests depend only on RFF. In this case, the NPV of 60 -year-old natural commercial forests was $\$ 9,370$ corresponding to $27 \% \mathrm{RFF}$, and the annual income of managing 1 ha of natural forest was $\$ 156 \mathrm{ha}^{-1} \mathrm{year}^{-1}$.

All the combinations of MAI, inflation rate, RFF, and interest rate resulted in NPV ranging from $\$ 1,024$ to $\$ 6,925 \mathrm{ha}^{-1}$ (Table 3). The lowest NPV was derived from the combination of MAI $=10 \mathrm{~m}^{3} \mathrm{ha}^{-1}$ year $^{-1}$, inflation rate $=2 \%, \mathrm{RFF}=27 \%$, and interest rate $=8 \%$ while the highest NPV was obtained when MAI $=20 \mathrm{~m}^{3} \mathrm{ha}^{-1}$ year $^{-1}$, inflation rate $=6 \%$, $\mathrm{RFF}=10 \%$, and interest rate $=4 \%$. The median value of all the NPV was $\$ 3,402 \mathrm{ha}^{-1}$ whereas the mean was $\$ 3,470 \mathrm{ha}^{-1}$, indicating that the NPV numbers were close to normal distribution.

The mean of the NPV derived with MAI $=10 \mathrm{~m}^{3} \mathrm{ha}^{-1}$ year $^{-1}$ was $\$ 1,761$ and increased to $\$ 3,470$ and $\$ 5,180$ with $\mathrm{MAI}=15$ and $20 \mathrm{~m}^{3} \mathrm{ha}^{-1}$ year ${ }^{-1}$, respectively (Fig. 2a). The Mann-Whitney $U$ test suggested that the three levels of MAI made significant differences in NPV $(P<0.01)$ (Table 6). The three levels of RFF resulted in NPV with three means of $\$ 3,499, \$ 3,488$, and $\$ 3,425$ for RFF $=10,18$, and $27 \%$, respectively (Fig. 2b). There was no significant difference in NPV between RFF levels of 10 and $18 \%$, 18 and $27 \%$, as well as 10 and $27 \%$ at the $95 \%$ confidence level. The mean of NPV values was $\$ 3,264$ when inflation rate $=2 \%, \$ 3,469$ when inflation rate $=4 \%$, and $\$ 3,678$ when inflation rate $=6 \%$ (Fig. 2c). Similar to RFF, the three levels of inflation rate resulted in no significantly different NPV. The interest rates of 4,6 , and $8 \%$ resulted in the means of NPV equal $\$ 4,496, \$ 3,388$, and $\$ 2,527$, respectively (Fig. 2d). Any two levels of interest rate, between 4.0 and $6.0 \%$, between 6.0 and $8.0 \%$, or between 4.0 and $8.0 \%$, made a significant difference in NPV $(P<0.05$ or $P<0.01)$.

The average EAI values was $\$ 351 \mathrm{ha}^{-1} \mathrm{year}^{-1}$, ranging from $\$ 120$ (when MAI $=10 \mathrm{~m}^{3} \mathrm{ha}^{-1}$ year $^{-1}$, inflation rate $=2 \%, \mathrm{RFF}=27 \%$, and interest rate $=8 \%$ ) to $\$ 623 \mathrm{ha}^{-1}$ year $^{-1}$ (when MAI $=20 \mathrm{~m}^{3} \mathrm{ha}^{-1}$ year $^{-1}$, inflation rate $=6 \%, \mathrm{RFF}=10 \%$, and interest rate $=4 \%$ ) (Table 4$)$.

The IRR ranged from 13.2 (when MAI $=10 \mathrm{~m}^{3} \mathrm{ha}^{-1} \mathrm{year}^{-1}$, inflation rate $=2.0 \%$, and $\mathrm{RFF}=27 \%$ ) to $29.3 \%$ (when MAI $=20 \mathrm{~m}^{3} \mathrm{ha}^{-1} \mathrm{year}^{-1}$, inflation rate $=6.0 \%$, and $\mathrm{RFF}=10 \%)\left(\right.$ Table 5). The mean of IRR derived with MAI $=10 \mathrm{~m}^{3} \mathrm{ha}^{-1}$ year $^{-1}$ was $16.5 \%$, and increased to 21.6 and $25.4 \%$ with MAI $=15$ and $20 \mathrm{~m}^{3} \mathrm{ha}^{-1}$ year $^{-1}$, respectively (Fig. 3a). The Mann-Whitney U test suggested that the three levels of MAI made significant differences in IRR $(P<0.01)$ (Table 6). There was no significant difference in IRR between three inflation rates of 2, 4 and $6 \%$ (Fig. 3b), nor between any two RFF levels of 10,18 and $27 \%$ at the $95 \%$ confidence level (Fig. 3c). 


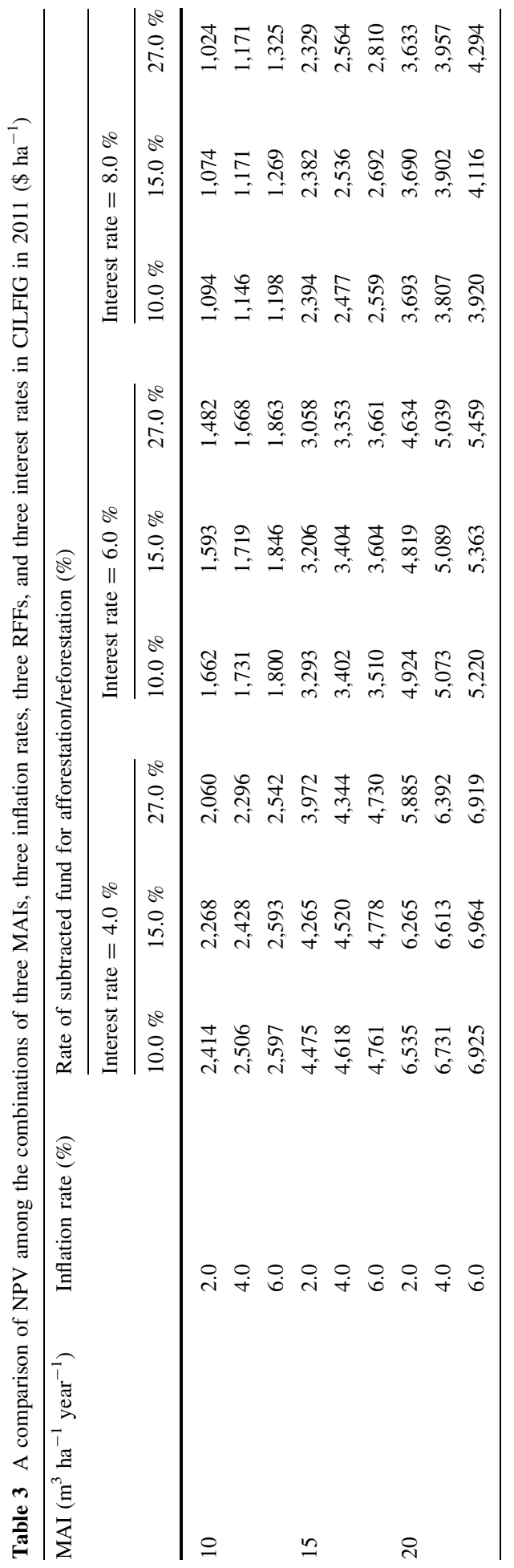



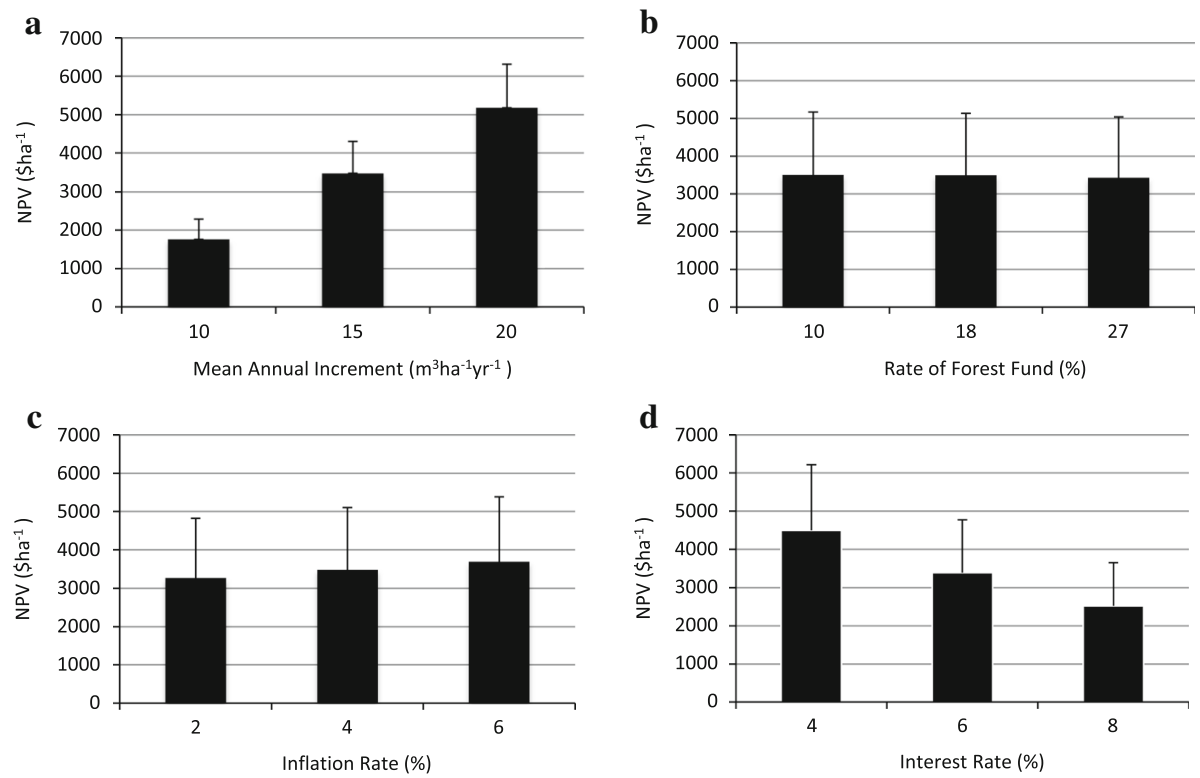

Fig. 2 A comparison of NPV among three levels of each NPV determinant and among four NPV determinants (a mean annual increment, b rate of forest fund, $\mathbf{c}$ inflation rate, and $\mathbf{d}$ interest rate) (US \$ per hectare at the 2011 value)

\section{Discussion}

The NPV numbers are determined by four variables but the values of each variable have an applicable range, which is the source of uncertainty of NPV estimations in CJFIG. The differences in the ranges among the variables mean differences in the effects of the determinants on NPV outcome. The MAI at its current range of $10-20 \mathrm{~m}^{3} \mathrm{ha}^{-1}$ year $^{-1}$ is the most important factor that regulates both NPV and IRR because it is the only factor that even a half of its range can significantly change the outcome of both NPV and IRR at the $99 \%$ confidence level. MAI is also the only factor that can be related to site conditions. Our finding is consistent with the report by Lopez et al. (2010), who suggested that site quality is more important than land price and transportation cost in determining timber investment returns for intensively managed pine plantations in Colombia. Currently, CJFIG still has potential to improve MAI by introducing hybrid poplars that have been successfully planted under the similar climate conditions in the cool temperate zone. For example, the MAI of poplar plantations can reach up to $31 \mathrm{~m}^{3} \mathrm{ha}^{-1}$ year ${ }^{-1}$ in the most southern Sweden (Christersson 2010) and $32 \mathrm{~m}^{3} \mathrm{ha}^{-1}$ year ${ }^{-1}$ in Coastal British Columbia of Canada (Zabek and Prescott 2006).

The current range of inflation rate (2-6\%) and a $2 \%$ difference between 2 and $4 \%$ make no significant different results in both NPV and IRR. A minor increase in inflation rate will not affect profitability of investment in poplar plantations in CJFIG. The possible range of RFF does not make significant difference in NPV and IRR either. Because at least part of RFF could be paid back to the forestry organization for afforestation or reforestation, there will be extra money for CJFIG to growth poplar plantations. In any case, RFF is not a significant factor CJFIG needs to be seriously concerned of. Interest rate, ranging 


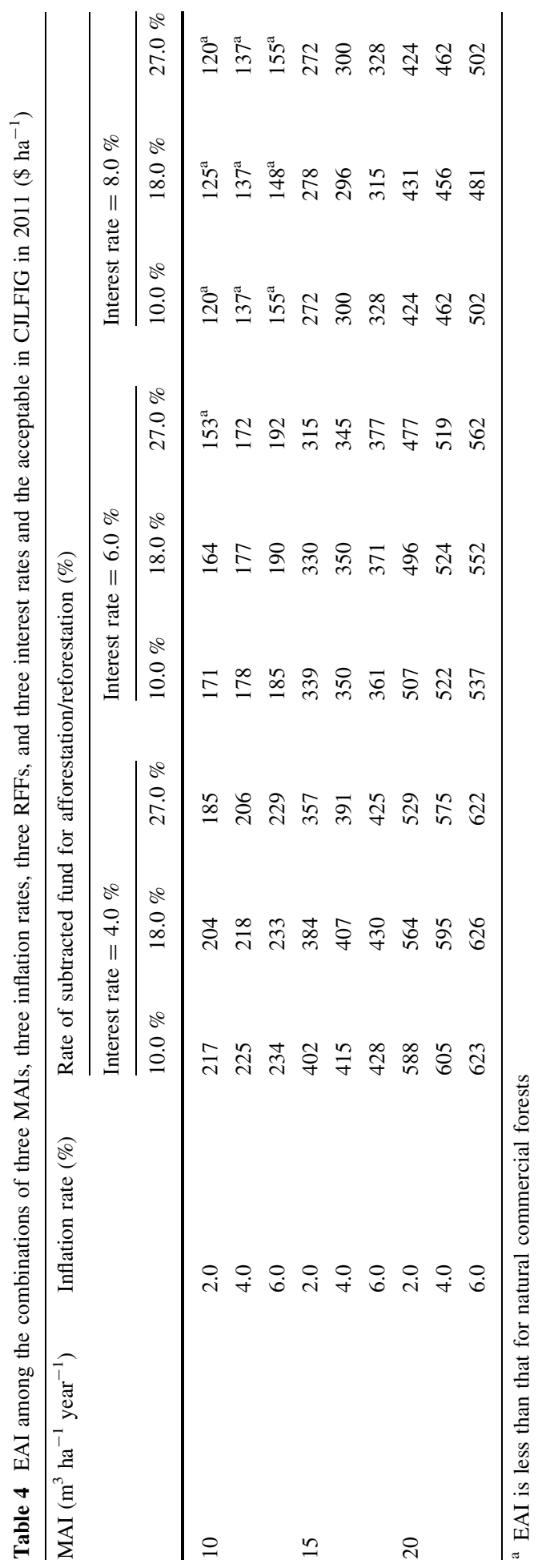


Table 5 IRR for three growth rates, three inflation rate and three afforestation fees in CJLFIG

\begin{tabular}{lllll}
\hline MAI $\left(\mathrm{m}^{3} \mathrm{ha}^{-1}\right.$ year $\left.^{-1}\right)$ & $\begin{array}{l}\text { Inflation } \\
\text { rate }(\%)\end{array}$ & \multicolumn{3}{l}{ Extraction rate of afforestation fund (\%) } \\
\cline { 4 - 5 } & & $10.0 \%$ & $18.0 \%$ & $27.0 \%$ \\
\hline \multirow{2}{*}{2.0} & 15.5 & 14.4 & 13.2 \\
& 4.0 & 17.7 & 16.6 & 15.2 \\
& 6.0 & 20.0 & 18.9 & 17.5 \\
& 2.0 & 20.5 & 19.3 & 17.9 \\
& 4.0 & 22.9 & 21.7 & 20.2 \\
& 6.0 & 25.2 & 24.0 & 22.5 \\
& 2.0 & 24.4 & 23.1 & 21.6 \\
& 4.0 & 26.8 & 25.5 & 24.0 \\
& 6.0 & 29.3 & 27.9 & 26.3 \\
\hline
\end{tabular}
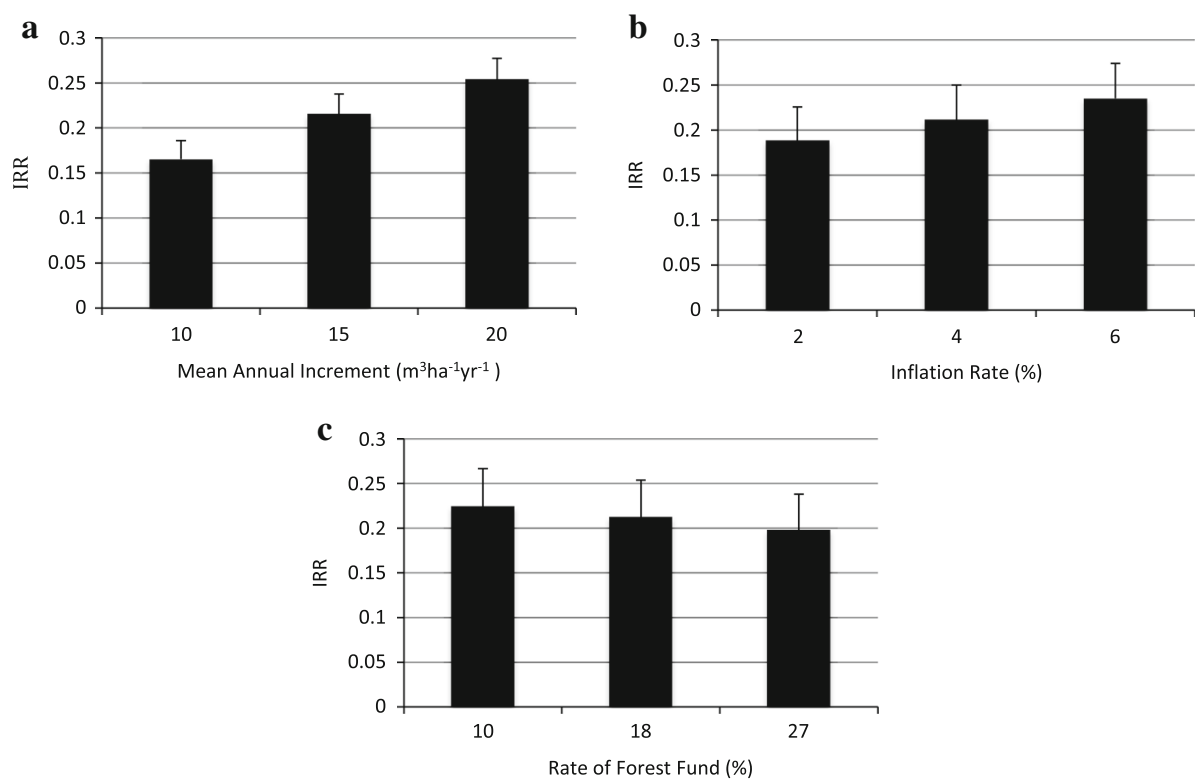

Fig. 3 A comparison of IRR among three levels of each IRR determinant (a mean annual increment, $\mathbf{b}$ inflation rate, and $\mathbf{c}$ rate of forest fund)

from 4, 6, $8 \%$, make significant difference in NPV. Currently, there is a $2 \%$ discount of forest loan as subsidy from the national government, which makes the real interest rate go down to $4 \%$ for forest enterprises and private forest landowners that apply for the funds of afforestation or reforestation. Further discount in the interest rate will make it more effective for increasing forestry profitability.

Within the current variations in the four determinants studied, there is a huge range of profitability in both NPV and IRR for growing poplar plantations in CJFIG. It is reasonable to set a profitability goal in the average level(s) of NPV and IRR. It is worth noting that even the middle level of IRR in CJFIG is much higher than that reported in growing other 
Table $6 P$ values of the Mann-Whitney U test

\begin{tabular}{llll}
\hline & Level 1 versus 2 & Level 2 versus 3 & Level 1 versus 3 \\
\hline NPV & & & 0.0000 \\
MAI & 0.0000 & 0.0000 & 0.3326 \\
Inflation rate & 0.4569 & 0.4261 & 0.8899 \\
RFF & 1.0000 & 0.9105 & 0.0001 \\
Interest rate & 0.0319 & 0.0348 & 0.0004 \\
IRR & & & 0.0521 \\
MAI & 0.0011 & 0.0081 & 0.2164 \\
Inflation rate & 0.2893 & 0.2893 & 1 \\
RFF & 0.5962 & 0.4799 & $2.0 \%, \mathrm{~L}$
\end{tabular}

MAI Level $1=10$, Level $2=15$, and Level $3=20 \mathrm{~m}^{3} \mathrm{ha}^{-1}$ year $^{-1}$; inflation rate Level $1=2.0 \%$, Level $2=4.0 \%$, and Level $3=6.0 \%$; RFF Level $1=10.0 \%$, Level $2=18.0 \%$, and Level $3=27.0 \%$; interest rate Level $1=4.0 \%$, Level $2=6.0 \%$, and Level $3=8.0 \%$

plantations in the temperate zone and is even comparable with that in sub-tropical and tropical regions (Cubbage et al. 2007). For example, timber-value based IRR is below $4 \%$ for red pine, Norway spruce, and black walnut plantations in southern Ontario, Canada (Yemshanov et al. 2007). IRR values of commercial poplar plantations in Serbia ranged from 4.3 to $6.9 \%$ (Keča et al. 2012). The reason why poplar plantations in CJFIG are so profitable is fourfold: (1) there is no land cost in the equation because forestland in the state-owned forest enterprises is a national property and provided free to grow forests; (2) labor costs are relatively low in forestry regions in China; (3) there is no income or capital tax at forest harvesting because the harvest timber is used within the forest enterprise; and (4) the wood material utilization rate is high as it is used to make wood boards. This demonstrates a major advantage for China's state own forest enterprises to grow commercial forests; and (5) forest policy-based loan with low discount rate has been assigned.

All but one of these poplar-plantation scenarios resulted in EAI greater than $\$ 156 \mathrm{ha}^{-1}$ year $^{-1}$ that was for the existing natural forests (Table 4). This means that growing poplar plantations are more economically effective than managing natural forests within the practical ranges of MAI, inflation rate and RFF under 4 and $6 \%$ discount rates. Converting natural forests to poplar plantations would be economically unacceptable when discount rate was $8 \%$ or greater and poplar forest MAI was $10 \mathrm{~m}^{3} \mathrm{ha}^{-1}$ year ${ }^{-1}$ or smaller. The combination of a high MAI, high inflation rate, low discount rate and low RFF can make the profit of poplar plantations four times higher than that of natural forests. Under present circumstances, growing fast-growing poplar plantations in CJFIG is generally more economically effective than managing natural commercial forests. The median of all the EAI values of poplar plantations was $\$ 350 \mathrm{ha}^{-1} \mathrm{year}^{-1}$, which was about two times more than current natural commercial forests.

\section{Conclusions}

The median of economic returns of growing fast-growing poplar plantations can be two times more than that of managing the existing natural commercial forests in CJFIG. Thus, the new 80,000 ha and the existing 18,000 ha of poplar plantations together will be equivalent to 178,000 ha of natural commercial forests in terms of economic benefit. Most 
of the natural commercial forests in CJFIG can be managed for ecological benefits in the same way as the local-level ecological forest is managed (Dai et al. 2013). Such a combination of commercial and ecological forests in a landscape will well maximize multiple services of forest ecosystems in the region. This assessment is actually based the average level of investment returns for the poplar plantations in CJFIG. If the right hybrid poplars are planted at the right sites, their MAI will be increased and, thus, economic benefit will be even greater. China's state-owned forest enterprises should take the advantages of zerocost forestland, tax-free policy, and loan-interest subsidy to expand their forest plantations. At the same time, the national government needs to update relevant forestry regulations to encourage market-based investment and harvesting of commercial forests in China.

Open Access This article is distributed under the terms of the Creative Commons Attribution License which permits any use, distribution, and reproduction in any medium, provided the original author(s) and the source are credited.

\section{References}

Bai GX (2009) Market-based forest maturity theory development and discussion. China Forestry Publishing House, Peking (in Chinese)

Bullard SH, Straka TJ (1998) Basic concepts in forest valuation and investment analysis. Preceda Education and Training, Auburn

Bullard SH, Straka TJ, Caulfield JP (2001) Inflation and the rule-of thumb method of adjusting the discount rate for income taxes. Can J For Res 31(1):52-58

Christersson L (2010) Wood production potential in poplar plantations in Sweden. Biomass Bioenergy 34:1289

Cubbage F, Donagh PM, Junior JS, Rubilar R, Donoso P, Ferreira A, Hoeflich V, Olmos VM, Ferreira G, Balmelli G, Siry J, Baez MN, Alvarez J (2007) Timber investment returns for selected plantations and native forests in South America and the Southern United States. New For 33:237-255

Cubbage F, Koesbandana S, Donagh PM, Rubilar R, Balmelli G, Olmos VM, Torre RDL, Murara M, Hoeflich VA, Turner J, Lord R, Huang J, Maclntyre C, McGinley K, Abt R, Phillips R (2010) Global timber investments, wood costs, regulation, and risk. Biomass Bioenergy 34:1667-1678

Dai LM, Zhao W, Shao GF, Lewis BJ, Yu DP, Zhou L, Zhou WM (2013) The progress and challenges in sustainable forestry development in China. Int J Sustain Dev World Ecol 20:394-403

Duerr DF (1960) Fundamentals of forestry economics. McGraw-Hill, New York, p 579

Elferjani R, DesRochers A, Tremblay F (2013) DRIS-based fertilization efficiency of young hybrid poplar plantations in the boreal region of Canada. New For 44:487-508

Freedman D, Pisani R, Purves R (2007) Statistics, 4th edn. W. W. Norton, New York

$\mathrm{He} \mathrm{H}, \mathrm{Xu}$ JT (2011) Projection of timber supply and demand trends in China based on an econometric model. For Prod J 61:543-551

Heilman P (1999) Planted forests: poplars. New For 17:89-93

Huang L, Liu JY, Shao QQ, Xu XL (2012) Carbon sequestration by forestation across China: past, present, and future. Renew Sustain Energy Rev 16:1291-1299

Keča L, Keča N, Pantic D (2012) Net present value and internal rate of return as indicators for assessment of cost-efficiency of poplar plantations: a Serbian case study. Int For Rev 14(2):145-156

Liberloo M, Calfapietra C, Lukac M, Godbold D, Luo ZB, Polle A, Hoosbeek MR, Kull O, Marek M, Raines C, Rubino M, Taylor G, Scarascia- Mugnozza G, Ceulemans R (2006) Woody biomass production during the second rotation of a bioenergy Populus plantation increases in a future high CO2 world. Glob Change Biol 12:1094-1106

Lopez J, Torre RDL, Cubbage F (2010) Effect of land prices, transportation cost, and site productivity on timber investment returns for pine plantations in Colombia. New For 39:313-328

Sedjo RA (1999) The potential of high-yield forestry for meeting timber needs. New For 17:339-359

Shao GF, Li CG (2010) An explanation on the rationality and necessity of market-based forest management in China: the case of Eucalyptus plantations in Guangxi. For Econ 8:113-115 (in Chinese)

Shao GF, Dai LM, Dukes JS, Jackson RB, Tang LN, Zhao JZ (2011) Increasing forest carbon sequestration through cooperation and shared strategies between China and the United States. Environ Sci Technol 45:2033-2034 
Tang LN, Shao GF, Dai LM (2009) Roles of digital technology in China's sustainable forestry development. Int J Sustain Dev World Ecol 16(2):94-101

Wagner JEDL (2012) Forest economics: a management approach. Taylor and Francis Group, London

Wang BN, Zhang YY, Tang JF, Chen JY, Wang HB (2008) Economic benefits analysis of Eucalyptus clones in China. For Prospect Des 2:20-23

Wilske B, Lu N, Wei L, Chen S, Zha T, Liu C, Xu W, Noormets A, Huang J, Wei Y, Chen J, Zhang Z, Ni J, Sun G, Guo K, McNulty S, John R, Han X, Lin G, Chen J (2009) Poplar plantation has the potential to alter the water balance in semiarid Inner Mongolia. J Environ Manag 90:2762-2770

Yemshanov D, McKenney D, Fraleigh S, D’Eon S (2007) An integrated spatial assessment of the investment potential of three species in southern Ontario, Canada inclusive of carbon benefits. For Policy Econ $10: 48-59$

Yu D, Zhou L, Zhou W, Ding H, Wang Q, Wang Y, Wu X, Dai L (2011) Forest management in Northeast China: history, problems, and challenges. Environ Manag 48(6):1122-1135

Zabek LM, Prescott CE (2006) Biomass equations and carbon content of aboveground leafless biomass of hybrid poplar in Coastal British Columbia. For Ecol Manag 223:291-302

Zhang YX, Song CH (2006) Impacts of afforestation, deforestation, and reforestation on forest cover in China from 1949 to 2003. J For 104:383-387 